\title{
A case of thyroid hormone resistance: a rare mutation
}

\author{
Caso de resistência aos hormônios tireóideos: mutação rara
}

Ana Pires Gonçalves', José Maria Aragüés', Ema Nobre', Ana Paula Barbosa', Mario Mascarenhas'

1 Serviço de Endocrinologia, Diabetes e Metabolismo do Hospital de Santa Maria, Centro Hospitalar Lisboa Norte, Portugal

\author{
Correspondence to: \\ Ana Pires Gonçalves \\ Rua Sousa Martins, $161 \mathrm{C}$ \\ 218-1050 - Lisboa, Portugal \\ aa.pgoncalves.hsm@gmail.com \\ Received on Feb/17/2014 \\ Accepted on May/31/2014 \\ DOI: $10.1590 / 0004-2730000003297$
}

\section{SUMMARY}

Reduced sensitivity to thyroid hormones (RSTH) is a rare disease that affects about 3,000 individuals, belonging to about 1,000 families. It results from reduced intracellular action of thyroid hormones (TH) genetically determined and manifests as persistent hyperthyroxinemia with non-suppressed thyroid-stimulating hormone (TSH). We describe a 67-years old, Caucasian woman, with past history of subtotal thyroidectomy due to diffuse goiter, who presents with a recurrence of goiter. Although she is clinically euthyroid, laboratory evaluation shows persistent hyperthyroxinemia with non-suppressed TSH. Response to thyrotropin releasing hormone (TRH) test was normal and TSH concentrations were not suppressed during oral administration of suprafisiologic doses of levothyroxine (L-T4). Peripheral blood DNA was extracted from the patient and a mutation was found localized in cluster one, at codon 346 of the ligand binding domain of the THRB gene. The patient's son underwent thyroid function testing (TFT) and genetic study, both negative, suggesting a sporadic mutation. RSTH should be considered in all hyperthyroxinemic patients who are clinically euthyroid. Mutations interfering with three major steps required for $\mathrm{TH}$ action on target tissues have been, so far, identified (TR- $\beta$, TR- $\alpha$, MCT8, SPB2). Each mutation is associated with a distinctive syndrome. Goal of management is to maintain a normal serum TSH level and a eumetabolic state and offer appropriate genetic counselling and prenatal diagnosis. Inappropriate treatment of eumetabolic patients results in hypothyroidism and need for TH replacement. Arq Bras Endocrinol Metab. 2014;58(9):962-6

\section{SUMÁRIO}

A sensibilidade reduzida aos hormônios tiroidianos (RSTH) é uma doença rara que afeta cerca de 3.000 indivíduos em 1.000 famílias. Ela resulta de uma ação intracelular reduzida de hormônios tiroidianos $(\mathrm{TH})$, é geneticamente determinada e se manifesta como hipertiroxinemia persistente com hormônio tireoestimulante (TSH) não suprimido. Descrevemos o caso de uma mulher caucasiana de 67 anos de idade com histórico de tiroidectomia subtotal por bócio difuso e que apresentou recorrência do bócio. Embora ela fosse clinicamente eutiroide, a avaliação laboratorial mostrou hipertiroxinemia persistente com TSH não suprimido. A resposta ao hormônio liberador da tireotrofina (TRH) foi normal e as concentrações deTSH não foram suprimidas durante a administração oral de doses suprafisiológicas de levotiroxina (L-T4). Foi extraído DNA de sangue periférico da paciente e encontrada uma mutação no cluster um do códon 346 do domínio de ligação do ligante do geneTHRB. O filho da paciente foi submetido a um teste de função da tiroide e a um estudo genético, ambos negativos, o que sugeriu uma mutação esporádica. O RSTH deve ser considerado em todos os pacientes hipertiroxinêmicos que sejam clinicamente eutiroides. Foram identificadas, até hoje, mutações que interferem com os três passos principais necessários para a ação do TH sobre os tecidos-alvo (TR- $\beta$, TR- $\alpha$, MCT8, SPB2). Cada mutação está associada com uma síndrome distinta. 0 objetivo do manejo é manter o nível sérico normal deTSH e um estado eumetabólico, além de se oferecer aconselhamento genético adequado e diagnóstico pré-natal. 0 tratamento inadequado de pacientes eumetabólicos leva ao hipotireoidismo e requer reposição de TH. Arq Bras Endocrinol Metab. 2014;58(9):962-6 


\section{INTRODUCTION}

$\mathrm{R}$ educed sensitivity to thyroid hormones (RSTH) is a rare disease, that affects about 3,000 individuals, belonging to about 1,000 families ( 1 ).

It results from reduced intracellular action of thyroid hormones $(\mathrm{TH})$ genetically determined and manifests as persistent hyperthyroxinemia with non suppressed TSH $(2,3)$.

Patients with RTH are usually euthyroid. Occasionally, they present signs and symptoms of thyrotoxicosis or, rarely, with hypothyroidism.

This condition is found with equal frequency in both genders and has wide geographic distribution having been reported in Caucasians, Africans, and Asians $(3,4)$. The prevalence may vary among different ethnic groups. Familial occurrence of RTH has been documented in approximately $75 \%$ of cases $(3,4)$.

Eighty-five percent of the patients harbour mutations in the thyroid receptor (TR) beta, and about one hundred of different mutations have been reported so far $(3,4)$. Most patients with RTH present missense mutations located exclusively in ligand-binding domain and hinge domain, most often clustered in three hot spots (exon 8-10). Investigation failed to demonstrate correlation between the phenotype and location of mutations in the receptor gene.

The diagnosis requires a high degree of suspicion, and is often delayed or failed, involving inappropriate treatment and morbidity for the patients.

In this article, we present a case of resistance to thyroid hormones, in which genetic testing revealed a rare mutation.

In this context, we review the literature, and highlight "pitfalls" in the investigations and treatment of this rare syndrome.

\section{CASE REPORT}

We report a case of a 67-years old woman, Caucasian, with past history of subtotal thyroidectomy due to diffuse goiter, who presents with a recurrence of goiter, persistent elevation of serum levels of FT4 and FT3 and non-suppressed TSH (TSH - $10.1 \mathrm{uU} / \mathrm{mL}(0.35$ - 5.50), FT3 - 6.21 pg/mL (2.3 - 4.2), FT4 - $2.3 \mathrm{ng} / \mathrm{dL}$ $(0.80-2.0)$. She is clinically euthyroid. There is no family history of goiter or other thyroid abnormalities. TBG, anti-TPO and anti-TG were within normal range. Response to TRH test (200 ug) was normal.
During oral administration of suprafisiologic doses of L - T4 (50, 100, $200 \mathrm{ug}$, each given for three days), TSH concentrations were not suppressed.

The goiter is well tolerated and the patient is euthyroid due to compensation of high levels of TSH, so no treatment was initiated.

Genomic DNA was isolated from peripheral blood. Exons 3-10 and 1-2 of THRB gene, including the flanking intronic sequences, were amplified by polymerase chain reaction (PCR) and screened by direct sequencing. Genetic study identified a heterozygous, missense mutation in exon 10, with c.1293G $>$ A transition inducing a replacement of isoleucine for methionine (p.Ile431Met). The mutation is localized in cluster one, at codon 346 of the ligand binding domain of the THRB gene.

The patient's son underwent thyroid function testing (TFT) and genetic study, both negative, suggesting a sporadic mutation.

\section{DISCUSSION}

We described a rare case of RSTH syndrome associated with an infrequent mutation.

The patient has clinical presentation and pattern of thyroid function test (TFT) abnormalities suggestive of RTH syndrome, which was confirmed by genetic test. Reviewing literature, we found a single previous report of a South American women presenting the same mutation $(5)$.

To our knowledge this is the first report of this specific mutations in Europe. Although, normally there is no correlation between phenotype and location of mutations in receptor gene, that woman was diagnosed with RTH at the age of 62 years old, and underwent inappropriate subtotal thyroidectomy due to goiter, similarly to our patient.

To avoid missing the diagnosis and inappropriate treatments, RSTH should be considered in all hyperthyroxinemic patients who are clinically euthyroid.

Mutations interfering with three major steps required for TH action on target tissues have been identified (TR- $\beta$, TR- $\alpha$, MCT8, SPB2) so far $(1,6-9)$. Each mutation is associated with a distinctive syndrome (Table 1). The TR- $\alpha$ gene defect was identified and reported only this year in two subjects $(1,8,9)$.

RTH results from mutations of TR- $\beta$ gene. Twenty-seven percent are de-novo mutations and $73 \%$ are inherited $(3,4)$. 
Table 1. Summary of thyroid abnormalities in the known syndromes of reduced sensitivity to thyroid hormone

\begin{tabular}{|c|c|c|c|c|c|c|c|c|}
\hline & Inheritance & Gene & Gene product & FT4 & FT3 & rT3 & TSH & Other manifestations \\
\hline \multirow{3}{*}{$\begin{array}{l}\text { Resistance to } \\
\text { TH (RTH) }\end{array}$} & \multirow{3}{*}{$\begin{array}{l}\text { Dominant } \\
\text { except in } \\
\text { one family }\end{array}$} & TR- $\beta$ (85\%) & TR- $\beta$ & \multirow[t]{3}{*}{ 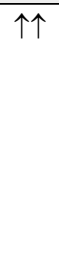 } & \multirow[t]{3}{*}{$\uparrow$} & \multirow[t]{3}{*}{ 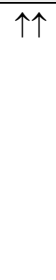 } & \multirow[t]{3}{*}{ Normal or slight $\uparrow$} & \multirow{3}{*}{$\begin{array}{l}\text { Eumetabolic vs Hypo and/or } \\
\text { hyperthyroidism }\end{array}$} \\
\hline & & & $\begin{array}{l}\text { Nuclear transcription factor of } \\
\text { specific gene targets }\end{array}$ & & & & & \\
\hline & & Unknown (15\%) & $\begin{array}{l}\text { Could be due to mosaism in a } \\
\text { denovo mutation or a yet } \\
\text { unidentified etiology (non-TR } \\
\text { RTH) }\end{array}$ & & & & & \\
\hline \multirow{2}{*}{$\begin{array}{l}\text { TH cell } \\
\text { transpoter } \\
\text { defect }\end{array}$} & \multirow[t]{2}{*}{ X-linked } & Мст8 & $\begin{array}{l}\text { Monocarboxylate transporter } 8 \\
\text { (MCT8) }\end{array}$ & \multirow[t]{2}{*}{$\downarrow$} & \multirow[t]{2}{*}{$\uparrow \uparrow$} & \multirow[t]{2}{*}{$\downarrow$} & \multirow[t]{2}{*}{ Normal or slight $\uparrow$} & \multirow[t]{2}{*}{ Sever psychomotor impairment } \\
\hline & & & $\begin{array}{l}\text { Transports T3 into neurons of } \\
\text { developing brain and TH into } \\
\text { other tissues }\end{array}$ & & & & & \\
\hline $\begin{array}{l}\text { TH } \\
\text { metabolism } \\
\text { defect }\end{array}$ & Recessive & SBP2 & $\begin{array}{l}\text { Selenocysteine insertion } \\
\text { sequence-binding protein (SBP2) } \\
\text { epistatic to selenoprotein } \\
\text { synthesis (including D1, D2, D3) }\end{array}$ & $\uparrow \uparrow$ & $\downarrow$ & $\uparrow \uparrow$ & Normal or slight $\uparrow$ & $\begin{array}{l}\text { Puberty delay infertility } \\
\text { Probably underestimated } \\
\text { (affected individuals are children) }\end{array}$ \\
\hline
\end{tabular}

$\uparrow:$ increased; $\downarrow$ : decreased; TH: thyroid hormone; TR- $\beta$ : thyroid hormone receptor beta.

In our case report, the patient's son underwent thyroid function testing (TFT) and genetic study, both negative, and there was no family history of thyroid disease, suggesting a sporadic mutation.

There are two different mutations, as described in figure 1 .

The less common, described in only one family, causes RTH by deletion of all coding sequences of the TR- $\beta$ gene and is inherited as an autosomal recessive trait $(3,4)$. In addition to typical RTH syndrome, these individuals have severe deafness resulting in mutism, and monochromatic vision. Heterozygous individuals for the same mutation have no abnormalities. Although, some TH effects are absolutely isoform specific, TR- $\beta$ and TR- $\alpha$ are interchangeable to a certain degree. There is no compensatory over expression of the single normal allele of TR- $\beta$ gene nor that of the TR- $\alpha$ gene $(3,4)$.
The most common form of RTH results from minor defects, in the ligand-binding domain or hinge domain of the TR- $\beta$ gene, resulting in impaired T3 binding, attenuated interaction with the coactivator or delay in the corepressor release. Mutant TR- $\beta$ gene (m TR- $\beta$ ) with impaired T3-bindind has a preserved DNA-binding domain and preserved ability to dimerize with homologous and heterologous partners, so it can interfere with the Wild Type TR (WT TR) function by occupying $\mathrm{TH}$ response elements (TRE) on target genes and by engaging WT TR- $\beta$ in homodimerization, a phenomenon termed dominant negative effect $(3,4,10)$. The reduced amount of wild type TR- $\beta$ does not produce haploinsufficiency by itself. It requires the dominant negative effect to cause RTH. The dominant negative effect also explains why this trait is inherited in a dominant fashion $(3,4,10)$.

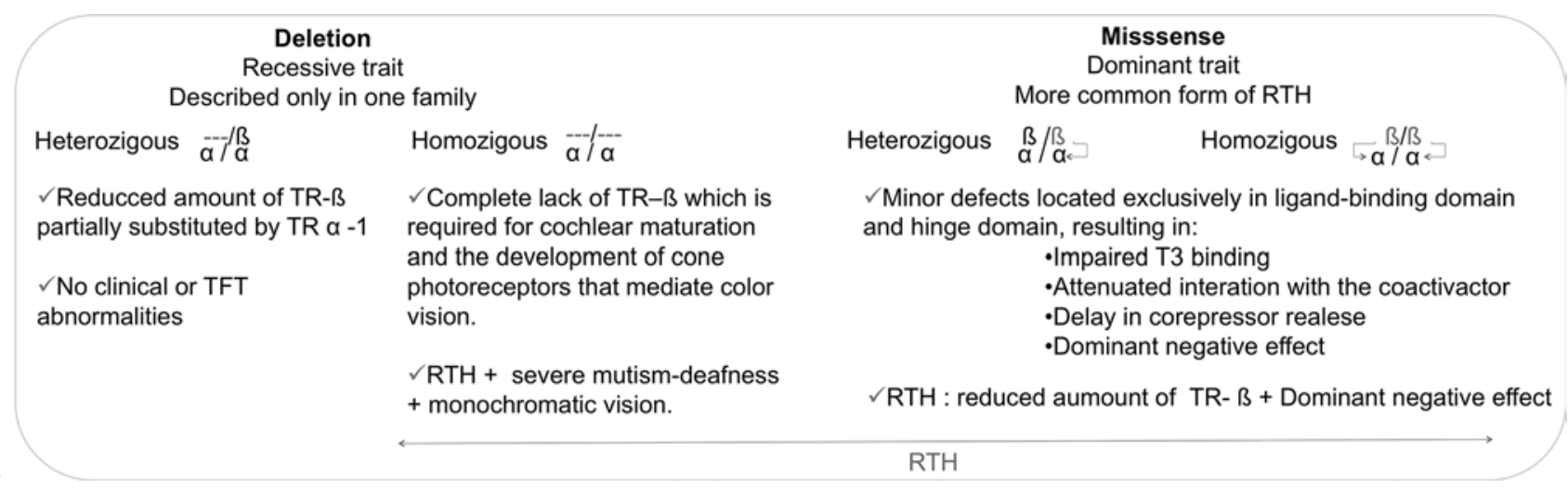

Figure 1. Resistance to thyroid hormone genotype. 
Most patients with RTH, such as the patient described, present missense mutations located exclusively in ligand-binding domain and hinge domain, most often clustered in three hot spots (exon 8-10) (6).

Failure to identify a TR- $\beta$ gene mutation in genomic DNA of subjects presenting the RTH phenotype could be due to mosaicism in a de-novo mutation or to a yet unidentified etiology of the syndrome (non-TR RTH) $(4,6)$.

All tissues share reduced sensitivity to $\mathrm{TH}$ to variable extent. Differences between tissues are due to absolute and relative levels of TR- $\beta$ and $\alpha$ expression during different stages of development. Inter and intra-familial variation is probably caused by genetically modulated cofactors $(3,4,6)$.

Despite a past history of thyroidectomy, the patient described was euthyroid and presented with recurrence of a small, non obstructive goiter. In this cases, TSH hypersecretion and/or hyperactivity is compensatory, and patients shouldn't receive treatment $(11,12)$.

When goiter isn't well tolerated it has been shown that treatment with supraphysiological doses of $\mathrm{L}_{-} \mathrm{T}_{3}$, given as a single dose every other day, is successful in reducing goiter size, without causing side effects $(11,12)$. This is the treatment of choice, considering that postoperative recurrence of goiter is the rule. The $\mathrm{L}_{-} \mathrm{T}_{3}$ dose must be adjusted in increments until TSH and TG are suppressed and reduction of goiter size is observed.

Discordance of resistance to $\mathrm{TH}$ between pituitary and other body tissues, leads to hypo and/or hyperthyroidism.

Hypothyroidism should be managed with individualized dose of $\mathrm{TH}$ guided by reduction of serum TSH concentration to normal (when TSH is increased) or markers of TH action (when TSH is within normal range) (11).
Parameters representative of peripheral $\mathrm{TH}$ action are for example: cholesterol, sex hormone-binding globulin (SHBG), angiotensin converting enzyme (ACE), carboxyterminal crosslinked telopeptide of type I collagen (ICTP), soluble interleukine-2 receptor (sIL-2r), and osteocalcin (4).

Those who, due to misdiagnosis, have undergone ablative therapy or present concomitant autoimmune disease, and as a consequence have limited thyroid reserve, will be managed as RTH presenting hypothyroidism.

In hyperthyroidism, first line is symptomatic treatment (11).

Atenolol is used to manage tachycardia and tremor, antianxiety drugs to alleviate nervousness.

Beta-blockers non-cardio selective should be avoided, because they inhibit peripheral T4 to T3 conversion, thus worsening of the hypothyroidism present in certain tissues.

Among agents with the potential to decrease TH through suppression of TSH, TRIAC, has been successful to reduce goiter size, and alleviate some symptoms, without a thyromimetic effect on peripheral tissues (compare to L-T3, TRIAC is eliminated faster and has high affinity for the $\beta$ but not $\alpha$ TR) (11).

Goal of management is to maintain a normal serum TSH level and a eumetabolic state and offer appropriate genetic counseling and prenatal diagnosis. Inappropriate treatment of eumetabolic patients results in hypothyroidism and need for TH replacement (Figure 2).

Although, RTH has been associated to other kind of neoplasia that requires vigilance (thyroid neoplasia, hepatocellular carcinoma, renal cell carcinoma...), there is no increased incidence of thyrotropic adenoma. Our patient hasn't present any other neoplasia to the moment.

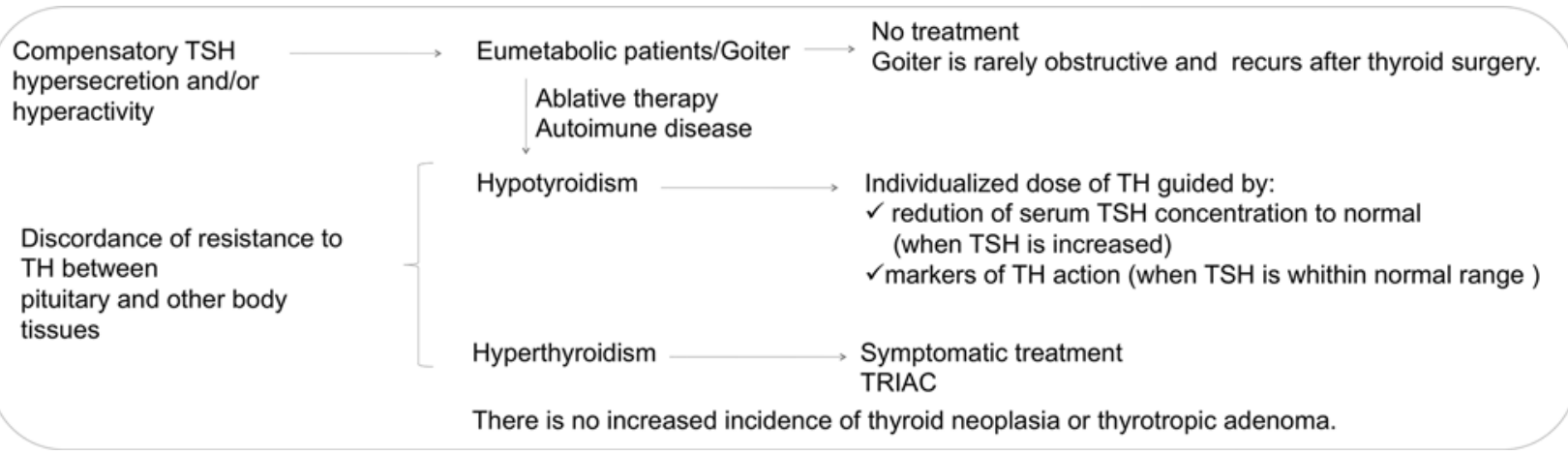

Figure 2. Current management strategies of resistance to thyroid hormone. 


\section{CONCLUSION}

Reduced sensitivity to thyroid hormone (RSTH) is more common then formerly suspected (3).

Cell-specific thyroid hormone $(\mathrm{TH})$ deprivation, sufficiency and excess can coexist in syndromes of RSTH.

Goiter and tachycardia are the most common reasons leading to testing and - ultimately - the diagnosis of RSTH (3).

Laboratory findings are very characteristic, almost pathognomonic, of RSTH $(3,4,6)$.

Genetic analysis of the suspected individuals is a short cut to diagnosis, but absence of a mutation does not rule out the suspected defect, particularly when dealing with mosaicism and non-TR RTH $(3,6)$. In such instances, a biochemical diagnosis should be secured by measuring the response to incremental doses of L-T4 and/or LT-3.

Inappropriate treatment in RSTH complicates the follow up and outcome.

Genetic factors, variability of tissue expression of iodothyronine cell membrane transports and intracellular enzymes could explain the lack of phenotype/genotype correlation (6).

Funding: this research did not receive any specific grant from any funding agency in the public, commercial or not-for-profit sector.

Disclosure: no potential conflict of interest relevant to this article was reported.

\section{REFERENCES}

1. Dumitrescu AM, Refetoff $S$. The syndromes of reduced sensitivity to thyroid hormone. Biochim Biophys Acta. 2013;1830(7):3987-4003.

2. Dumitrescu AM, Refetoff S. Hot thyroidology. Available at: www. hotthyroidology.com.

3. Refetoff S, Dumitrescu AM. Syndromes of reduced sensitivity to thyroid hormone: genetic defects in hormone receptors, cell transporters and deiodination. Best Pract Res Clin Endocrinol Metab. 2007;21(2):277-305.

4. Thyroid disease manager. Available at: www.thyroidmanager. org/Chapter16/chapter16d.pdf.

5. Rivolta CM, Olcese MC, Belforte FS, Chiesa A, Gruñeiro-Papendieck L, lorcansky $S$, et al. Genotyping of resistance to thyroid hormone in South American population. Identification of seven novel missense mutations in the human thyroid hormone receptor beta gene. Mol Cell Probes. 2009;23(3-4):148-53.

6. Weiss RE, Refetoff $S$. Resistance to thyroid hormone (RTH) in the absence of abnormal thyroid hormone receptor (TR) (non TR- RTH). Hot Thyroidology. Available at: www.hotthyroidology. com.

7. van Mullem A, van Heerebeek R, Chrysis D, Visser E, Medici M, Andrikoula $M$, et al. Clinical phenotype and mutant TR $\alpha 1$. N Engl J Med. 2012;366(15):1451-3.

8. Bochukova E, Schoenmakers N, Agostini M, Schoenmakers E, Rajanayagam $\mathrm{O}$, Keogh JM, et al. A mutation in the thyroid hormone receptor alpha gene. N Engl J Med. 2012;366(3):243-9.

9. Wu SY, Cohen RN, Simsek E, Senses DA, Yar NE, Grasberger H, et al. A novel thyroid hormone receptor-beta mutation that fails to bind nuclear receptor corepressor in a patient as an apparent cause of severe, predominantly pituitary resistance to thyroid hormone. J Clin Endocrinol Metab. 2006;91(5):1887-95.

10. Carvalho GA, Ramos HE. Thyroid hormone resistance syndrome. Arq Bras Endocrinol Metab. 2004;48:83-92.

11. Weiss R, Refetoff S. Editorial: Treatment of resistance to thyroid hormone - Primum Non Nocere. J Clin Endocrinol Metab. 1999;84(2):401-4.

12. Kim TJ, Travers S. Case report: thyroid hormone resistance and its therapeutic challenges. Curr Opin Pediatr. 2008;20(4):490-3. 